\title{
PERANCANGAN APLIKASI PERHITUNGAN INDEKS ICT-PURA PROVINSI SULAWESI UTARA
}

\author{
Wahjoe Dyah Ayuningtyas ${ }^{1)}$, Yaulie Rindengan ${ }^{2)}$, Virginia Tulenan ${ }^{3)}$, Stanley Karouw ${ }^{4)}$ \\ ${ }^{1,2,3,4}$ Program Studi Teknik Informatika, Fakultas Teknik, Universitas Sam Ratulangi \\ Jl. Kampus UNSRAT Bahu, Manado, 95115 \\ Telp : (0431) 852959, Fax : (0431) 823705 \\ E-mail: Wahjoedyah@gmail.com ${ }^{1)}$, stanley.karouw@unsrat.ac.id ${ }^{4)}$
}

\begin{abstract}
Abstrak
Perkembangan TIK yang pesat membuat pemerintah mengadakan suatu penghargaan yaitu ICTPURA. Penghargaan ini diberikan kepada kabupaten/kota yang wilayah yang sudah berbasis Digital city yaitu sebuah kota yang berhasil mengelola TIK dengan baik sehingga memberikan kontribusi manfaat yang signifikan terhadap sistem kehidupan masyarakatnya. Dari hasil pengamatan yang telah dilakukan, semua prosedur perhitungan mulai dari Pengisian Kuisioner dan perhitungan indeksnya masih dilakukan secara manual. Untuk mengatasi masalah tersebut dibangunlah Aplikasi Perhitungan Indeks ICT-PURA Berbasis Web di Sulawesi Utara. Paper ini menjelaskan proses perancangan aplikasi dengan menggunakan metodologi yang berorientasi objek, berbasis web dengan karakteristik agile; yaitu metodologi DAD (disciplined agile delivery, dengan panduan Pusilkom Agile Unified Process (PAUS). Aplikasi ini dibangun menggunakan tools Crimson Editor dengan source Wamppserver. Aplikasi Perhitungan Indeks ICT-PURA berbasis web diharapkan dapat meningkatkan efisiensi perhitungan indeks ICT-Pura pada tingkat provinsi.
\end{abstract}

Kata kunci : DAD, ICT-PURA, Perhitungan Indeks

\section{PENDAHULUAN}

Perkembangan TIK yang pesat membuat, pemerintah mengadakan suatu penghargaan yaitu ICT-PURA. Penghargaan ini diberikan kepada kabupaten/kota yang wilayahnya itu sudah berbasis Digital city yaitu sebuah kota yang berhasil mengelola TIK dengan baik sehingga memberikan kontribusi manfaat yang signifikan terhadap sistem kehidupan masyarakatnya.

Program ICT-PURA ini di rancang untuk memenuhi sejumlah objektif utama yaitu, untuk mengetahui tingkat kesiapan setiap kabupaten dan kota dalam menghadapi era ekonomi digital, untuk mengukur besaran gap riil antara target dan kondisi sebenarnya pada setiap strategi nasional untuk menghasilkan solusi, serta untuk memberikan motivasi, dukungan, insentifif, dan apresiasi bagi kabupaten dan kota yang bekerja keras dan mempersiapkan diri dalam menghadapi era digital melalui beragam program pembangunan dan penerapan tik di wilayah masing-masing.

Program ICT-PURA lainnya juga agar dapat mengilustrasikan situasi kesiapan daerah yang sesungguhnya dalam menghadapi tantangan pengembangan TIK, termasuk mengukur besaran digital divide (kesenjangan digital) antar daerah. Sehingga dari kondisi nyata tersebut akan dipetakan kekuatan, kelemahan, tantangan, dan peluang dapat disusun strategi pemecahan masalah serta optimalisasi hasil yang telah dicapai. Dalam beberapa tahun terakhir, pemerintah di seluruh indonesia, termasuk Sulawesi utara khususnya di 5 kota yang dipilih oleh kominfo untuk perwakilan dari program ictpura ini yaitu Manado, Tomohon, Minahasa Selatan, Bitung dan bolaang mongodow.

Masalah yang ingin dijawab dalam penelitian ini adalah bagaimana membangun aplikasi berbasis web untuk perhitungan indeks ICTPURA di provinsi Sulawesi Utara?

\section{LANDASAN TEORI}

\subsection{TEKNOLOGI INFORMASI DAN KOMUNIKASI}

Menurut kurniawan dan rahmat (2010) Teknologi Informasi dan Komunikasi, TIK (bahasa Inggris: Information and Communication Technologies; ICT) adalah "payung besar terminologi yang mencakup seluruh peralatan teknis untuk memproses dan menyampaikan informasi."

Dalam teknologi informasi dan komunikasi terdapat aspek yang termasuk ke dalamnya, yaitu teknologi informasi dan teknologi komunikasi. Kedua aspek ini hanya berbeda fungsi.

Kedua mempunyai pengertian yang berbeda tetapi mempunyai kesamaan yaitu bertujuan menbantu seseorang untuk menyampaikan informasi dan mendapatkan informasi dengan mudah dan tepat. Komunikasi merupakan suatu proses yang dilakukan orang untuk menyampaikan informasi atau gagasan dengan tujuan untuk 
mengubah atau membentuk perilaku seseorang, yang semula tidak mengetahui apapun menjadi mengetahui sesuatu.

Sedangkan informasi adalah suatu berita atau pengumuman yang diproses sedemikian rupa sehingga menjadi sesuatu yang dapat disebarkan atau diberitahukan ke orang lain, dengan tujuan untuk memberikan suatu berita atau pengumuman menjadi suatu yang bermanfaat bagi orang lain baik individu maupun kelompok.

\subsection{ICT PURA}

Menurut buku profil dan panduan pelaksanaan program ict-pura Kementrian Komunikasi dan Informasi RI (2011) Istilah ICT Pura pada dasarnya berkaca pada keberhasilan pemerintah Indonesia dalam memperkenalkan konsep penghargaan "Adipura" - yang diberikan kepada daerah otonom yang dianggap berhasil mengelola lingkungan yang bersih dan sehat. Secara arti kata yang membentuknya, ICT pura berarti "Kota TIK" atau dalam bahasa asingnya sering diistilahkan sebagai "Digital City" - sebuah kota yang berhasil mengelola TIK dengan baik sehingga memberikan kontribusi manfaat yang signifikan terhadap pengembangan masyarakatnya.

Secara umum, Program ICT Pura terbagi menjadi 3 (tiga) domain kegiatan sebagai berikut:

1. Pemetaan Entitas ICT Pura (PE-Pura) adalah proses dan aktivitas untuk memetakan profil kesiapan masing-masing kota/kabupaten di Indonesia dalam menghadapi era komunitas digital secara lengkap dan komprehensif dengan memperhatikan berbagai domain aspek pengukuran;

2. Penghitungan Indeks ICT Pura (PI-Pura) adalah proses dan aktivitas untuk menghitung indeks kesiapan masing-masing kota/kabupaten dalam menghadapi era komunitas digital sebagai alat untuk melihat besaran gap yang terjadi antara target dan kondisi sebenarnya (baca: digital gap);

3. Pemberian Apresiasi ICT Pura (PA-Pura) adalah proses dan aktivitas pemberian apresiasi terhadap kota/kabupaten yang dianggap memiliki prestasi dalam mempersiapkan diri menghadapi era komunitas digital.

Perlu diperhatikan bahwa ketiga domain kegiatan ini adalah suatu rangkaian proses dan aktivitas yang saling berhubungan. Hasil pemetaan akan dipergunakan sebagai penghitungan indeks, sementara hasil penghitungan indeks akan dijadikan sebagai dasar dalam memberikan penghargaan atau apresiasi

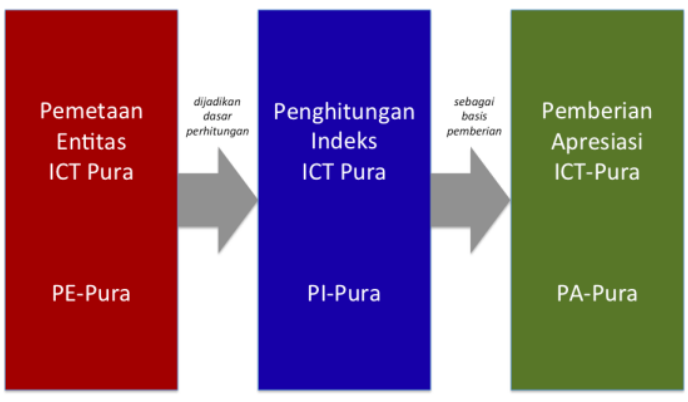

Gambar 1. Proses Penetapan ICTPura

\subsection{TEORI PERHITUNGAN INDEKS ICT PURA}

\subsubsection{Indeks Ict_Pura}

Sesuai dengan referensi yang disampaikan oleh ITU dan WSIS, paradigma pengukuran indeks adalah seperti model pada Gambar 2 berikut ini:

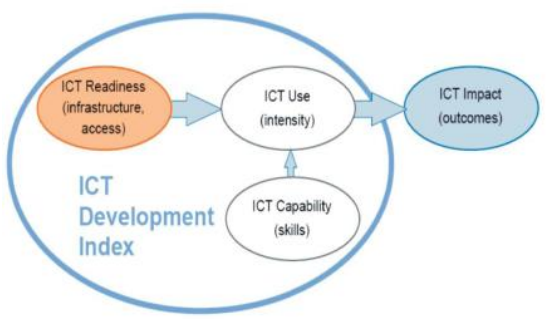

Gambar 2. Model ICT Development Index

ICT Development Index (IDI) adalah indeks yang diterbitkan oleh Uni Telekomunikasi Internasional Perserikatan Bangsa-Bangsa berdasarkan informasi yang disepakati secara internasional dan teknologi informasi indicator. IDI ini juga adalah sebagai alat standar yang pemerintah, operator, badan pembangunan, peneliti dapat gunakan untuk mengukur kinerja ICT dalam lintas Negara. IDI ini bersifat umum, walaupun keempat komponen yang ada mencerminkan empat aspek utama dalam ekosistem TIK di sebuah kota/kabupaten. Untuk model penghitungan lebih detail akan sangat bergantung pada konteks, obyektif, dan ketersediaan data yang dimiliki.

\subsection{KOMPONEN PERHITUNGAN INDEKS}

Menurut Kementrian Komunikasi dan Informasi RI dalam dari buku profil dan panduan pelaksanaan program ict-pura (2011). terkait dengan ICT Pura, sejumlah komponen-komponen penghitungan indeks yang diadopsi adalah sebagai berikut:

1. ICT Use (Intensity) - Mengingat bahwa kota/kabupaten dipimpin oleh unsur pemerintah (dalam hal ini dikepalai oleh Walikota atau Bupati), dan seluruh keigatan dalam konteks kemasayrakatan akan sangat diwarnai dengan berbagai kebijakan, peraturan, dan berbagai keputusan dari 
pemerintah daerah, maka bobot yang terkait dengan peranan pemerintah dalam mengelola TIK di kotanya haruslah terbesar - paling tidak $40 \%$;

2. ICT Readiness (Infrastructure) Mempertimbangkan bahwa ketersediaan infrastruktur TIK pada dasarnya adalah sebuah keputusan bisnis/industri penyedia jasa infrastruktur yang sangat dipengaruhi oleh peluang/potensi pasar di satu pihak dan keputusan pemerintah pusat di pihak lain, dan tidak mungkin aplikasi TIK akan berjalan tanpa keberadaan infrastruktur minimum, maka bobot untuk komponen ini paling tidak minimal 20\%;

3. ICT Capability (Skills) - Melihat bahwa sebuah kota/kabupaten hanya dapat berkembang jika memiliki sumber daya dan kemampuan yang cukup, dimana keseluruhannya sangat dipengaruhi oleh kemampuan komunitas dalam mengeksplorasi dan mengeksploitasi aset TIK yang dimiliki, maka untuk komponen ini perlu diberi bobot sekitar 25\% maksimum; dan

4. ICT Impact (Outcomes) - Mempelajari bahwa pada akhirnya, tidak ada gunanya membangun TIK jika masyarakat atau kota/kabupaten yang bersangkutan tidak memperoleh manfaat langsung dari keberadaannya, maka bobot untuk portofolio manfaat paling tidak adalah minimal $15 \%$.

Rumusan perhitungan indeks ICT-Pura (Gambar 3) adalah sebagai berikut :

\begin{tabular}{|c|}
\hline Indeks ICT Pura $=$ NRIU $* 40 \%+$ \\
NRIR $* 20 \%+$ NRIC $* 25 \%+$ NRII $* 15 \%$ \\
\hline Gambar 3. Rumusan Perhitungan Indeks
\end{tabular}

dimana:

NRIU = Nilai Rata-Rata Komponen ICT Usage

NRIR = Nilai Rata-Rata Komponen ICT Readiness NRIC = Nilai Rata-Rata Komponen ICT Capability NRII = Nilai Rata-Rata Komponen ICT Impact

\subsection{METODE PERANCANGAN SISTEM}

\subsubsection{Disciplined Agile Delivery (DAD)}

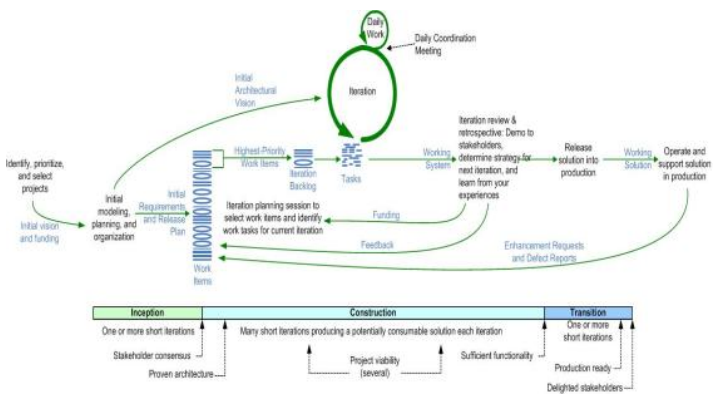

Gambar 4. Metodologi DAD
Disciplined Agile Delivery Lifecycle memperluas pada siklus konstruksi Scrum dalam tiga hal penting:

- Ini memiliki proyek fase eksplisit, mengakui bahwa pengiriman tangkas benar benar berulang dalam seri kecil dan dalam lingkup besar.

- Ini mencakup berbagai macam praktik. Ini termasuk persyaratan awal dan membayangkan seperti arsitektur pada awal proyek untuk meningkatkan kesempatan membangun produk yang tepat dengan cara yang tepat, serta praktek rilis sistem.

- Ini termasuk praktik lebih kuat. Siklus hidup tokoh ini secara eksplisit mengolah kembali backlog produk dalam slide sebelumnya ke dalam konsep yang lebih akurat dari pekerjaan item daftar peringkat. Tidak hanya tim pengiriman tangkas menerapkan persyaratan fungsional, mereka juga harus memperbaiki cacat (ditemukan melalui pengujian independen atau dengan pengguna versi yang ada dalam produksi), memberikan umpan balik pada pekerjaan dari tim lain, mengambil kursus pelatihan, dan sebagainya. (www.ambysoft.com / esai / agileLifecycle.html)

\subsubsection{Panduan Pusilkom Agile Unifed Process (PAUS)}

Panduan Pusilkom Agile Unified Process (atau PAUS) merupakan suatu metodologi pengembangan perangkat lunak yang ditujukan untuk industry kecil dan menengah.

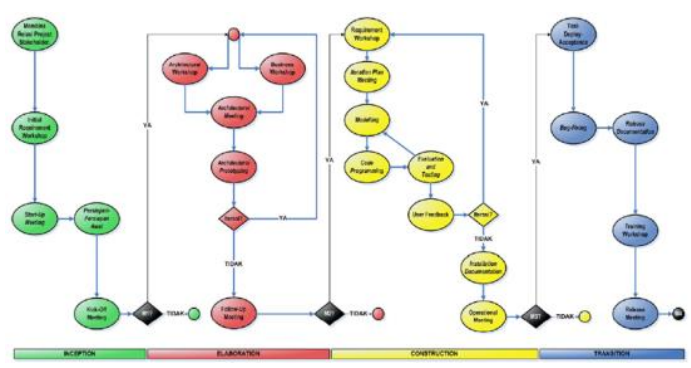

Gambar 5. Urutan Aktivitas Panduan PAUS

Tahapan pemecahan masalah dengan Panduan PAUS, mengikuti langkah-langkah metodologi yang dibuat oleh Ambysoft Inc. (http://ecl.cs.ui.ac.id/PAUS/Index.html di akses 18 Juli 2012). Garis besar tahapan analisa dan perancangan yang dilakukan adalah sebagai berikut:

1) Inception, dengan aktivitas mendefinisikan project scope, mengestimasi biaya dan penjadwalan, mendefinisikan resiko, membuat kelayakan proyek dan mempersiapkan lingkungan pengerjaan proyek (tim, tempat kerja, instalasi, dan sebagainya). Proses iterasi dilakukan satu kali. Artifak yang dihasilkan diantaranya adalah 
dokumen Vision, dokumen Supplementary Specification, dokumen Glossary, Gantt Chart dan Iteration Plan.

2) Elaboration, dengan aktivitas mengidentifikasi dan validasi arsitektur aplikasi. Proses iterasi dapat dilakukan satu sampai dua kali. Artifak yang dihasilkan adalah UML Use Case, Model Arsitektur (update dan snapshot), Architecture Prototype Code, Scenario Test Plan, dokumen Business Rule, dokumen Supplementary dan Glossary yang telah diupdate.

3) Construction, dengan aktivitas memodelkan, membangun dan menguji sistem aplikasi (unit testing) serta membuat dokumentasi pendukung. Proses iterasi dapat dilakukan dua hingga delapan kali. Artifak yang dihasilkan adalah Use Case (yang telah diupdate), dokumen Supplementary dan Glossary (yang telah diupdate), Domain Model (snapshot), UML Activity Diagram (snapshot), UML Class Diagram (snapshot), CRC Card, UML Sequence Diagram (snapshot), Source Code, Code Documentation, Regression Test Suite, Acceptance Test dan Bugs Report.

4) Transition, dengan aktivitas menguji sistem (integration sistem dan user testing), mereview kembali sistem aplikasi dan menginstalasi sistem aplikasi. Proses iterasi dapat dilakukan satu hingga dua kali. Artifak yang dihasilkan adalah Dokumen System Requirement Specification, Dokumen System Technical Specification, Panduan Instalasi dan Panduan Pengguna, Dokumen Pelatihan, Regression Test Suite, User Acceptance Test dan Bugs Report (yang sudah final).

Perancangan Aplikasi Perhitungan Indeks ICTPURA di Provinsi Sulawesi Utara akan dirancang hanya sampai pada tahap ketiga yaitu pada fase Konstrusi, dan tidak akan sampai pada fase transition atau implementasinya. Karena aplikasi ini ada di implementasikan di Dinas Komunikasi dan Informasi Kota Manado.

\section{PEMBAHASAN}

Pada bagian pembahasan, penulis akan menampilkan tahapan-tahapan yang berkaitan dengan metodologi DAD yang berpanduan pada metodologi AGILE yang digunakan dalam membangun aplikasi perhitungan indeks berbasic web ini. Tahapan- Tahapan ini memiliki tujuan aktivitas proses, dimana aktivitas proses tersebut menghasilkan artifak atau dokumentasi aplikasi yang dibangun.

\subsection{Tahap Inception}

Target utama fase inception adalah memahami cakupan dan tujuan proyek serta memperoleh cukup informasi yang bisa mengkonfirmasi bahwa kita harus jalan terus (atau sebaliknya mengapa tidak perlu diteruskan). Lima tujuan dasar fase inception adalah: a) Memahami apa yang hendak dibangun. Menentukan visi, cakupan sistem dan batasannya; b) Mengidentifikasi fungsionalitas sistem; c) Menentukan setidaknya satu solusi yang paling mungkin; d) Memahami ongkos, jadwal dan resiko yang berkaitan dengan proyek; e) Menentukan proses apa yang harus diikuti dan tools mana yang akan digunakan.

Artifak yang dihasilkan dari aktivitas proses inception; diantaranya adalah: proses bisnis aplikasi, problem statement, fungsionalitas utama yang akan dikembangkan, estimasi software, kelayakan financial dan daftar resiko.

Proses bisnis aplikasi, dapat dilihat pada Gambar 6. Sedangkan untuk fungsionalitas utama aplikasi yang akan dikembangkan dapat dilihat pada Tabel 1 .

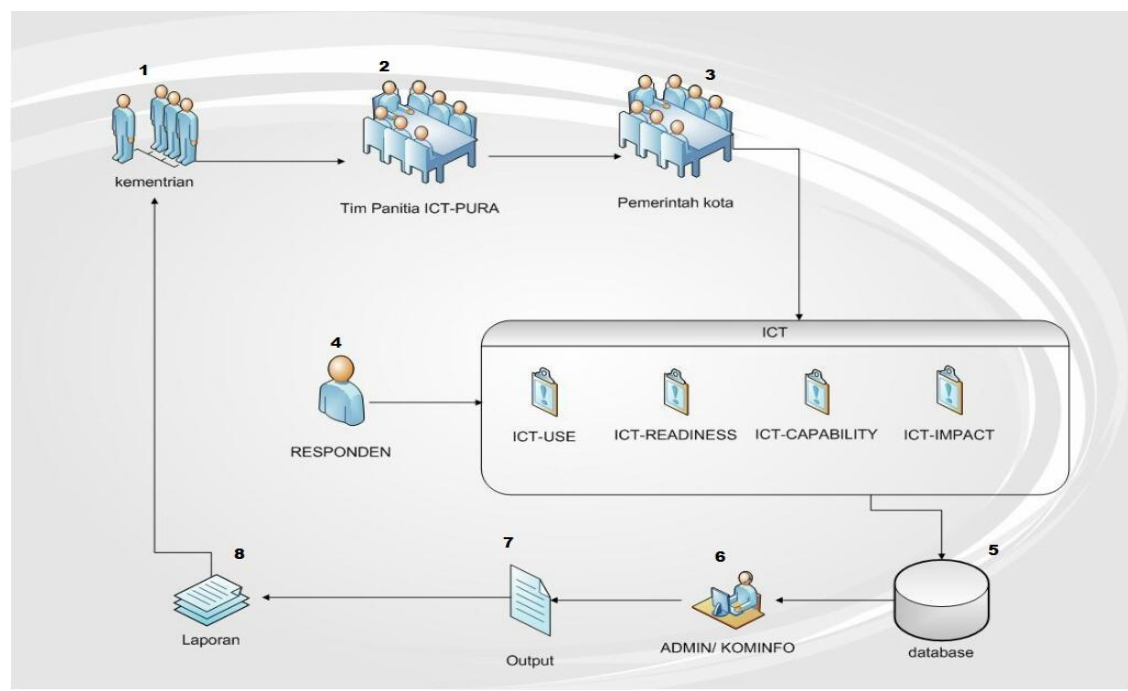

Gambar 6. Proses Bisnis aplikasi perhitungan indeks ICT-PURA 
Untuk estimasi software dihitung dengan tools Function Point Analysis; menghasilkan Total Adjucted Function Point (TAFP) sebanyak 73,92, dengan jumlah Lines of Code (LOC) sebanyak 1035 baris (menggunakan HTML, php dan JavaScript). Estimasi waktu pengerjaan sebanyak 3 bulan, dengan jumlah tim pengembangan 2 orang. Sementara untuk kelayakan financial aplikasi web dihitung dengan tools Net Present Value (NPV), Return on Investment (ROI) dan Break Event Point (BEP). Total Yearly NPV sebesar Rp. 3.018.868 (dalam empat tahun), dengan ROI 87,5\% dan BEP 3,62 tahun.

Table 1. Fungsionalitas Utama Aplikasi

\begin{tabular}{|c|c|}
\hline \multicolumn{2}{|c|}{ Functional Requirements } \\
\hline \multicolumn{2}{|l|}{ A. Respondent } \\
\hline \multirow[t]{2}{*}{ 1. Melakukan Login } & 1.1 Login respondent \\
\hline & 1.2 respondent viewing \\
\hline \multirow[t]{2}{*}{ 2. Mengisi kuisioner } & $\begin{array}{l}2.1 \text { respondent mengisi } \\
\text { kuisioner (sesuai katagori } \\
\text { respondent) }\end{array}$ \\
\hline & $\begin{array}{l}2.2 \text { Respondent } \\
\text { mengunduh dokumen } \\
\text { yang terkait dengan } \\
\text { kuisioner (dokumen atau } \\
\text { catatan) }\end{array}$ \\
\hline \multicolumn{2}{|l|}{ B. Admin } \\
\hline 1. Melakukan Login & 1.1 Login Administrator \\
\hline \multirow[t]{5}{*}{ 2. Mengolah Data } & $\begin{array}{l}2.1 \text { admin dapat } \\
\text { melakukan input, edit, } \\
\text { update, dan hapus } \\
\text { pengaturan admin }\end{array}$ \\
\hline & $\begin{array}{l}2.2 \text { admin dapat } \\
\text { melakukan input, edit, } \\
\text { update, dan hapus } \\
\text { informasi }\end{array}$ \\
\hline & $\begin{array}{l}2.3 \text { admin dapat } \\
\text { melakukan input, edit, } \\
\text { update, dan hapus } \\
\text { kuisioner }\end{array}$ \\
\hline & $\begin{array}{l}2.4 \text { admin dapat } \\
\text { melakukan input, edit, } \\
\text { update, dan hapus } \\
\text { respondent }\end{array}$ \\
\hline & $\begin{array}{l}2.5 \text { admin dapat } \\
\text { melakukan input, edit, } \\
\text { update, dan hapus Banner }\end{array}$ \\
\hline \multirow[t]{2}{*}{ 3. Viewing score } & $\begin{array}{l}\text { 3.1 Melihat hasil } \\
\text { perhitungan indeks ICT- } \\
\text { PURA }\end{array}$ \\
\hline & 3.2 Melihat Buku Tamu \\
\hline \multicolumn{2}{|c|}{ Non Functional Requirements } \\
\hline $\begin{array}{l}\text { 1. Operational } \\
\text { Requirements }\end{array}$ & \begin{tabular}{l|l} 
1.1 Aplikasi dapat \\
dijalankan pada \\
Sistem Windows 7 \\
1.2 Bahasa yang \\
digunakan adalah \\
Bahasa Indonesia
\end{tabular} \\
\hline
\end{tabular}

\begin{tabular}{|l|l|}
\hline 2. Performance & 2.1 Waktu respon \\
Requirements & ke web server harus \\
& dibawah 10 detik. \\
& Meskipun ada \\
& kemungkinan lain \\
& dari segi koneksi \\
data
\end{tabular}

\subsection{Tahap Elaboration}

Elaboration adalah fase kedua dalam siklus pengembangan software. Target fase ini adalah menentukan arsitektur basis sistem yang menjadi landasan disain dan implementasi di fase construction. Target global ini terbagi ke dalam empat tujuan, masing-masing menangani sebuah resiko utama, sebagai berikut: a) Pemahaman kebutuhan yang lebih detail.; b) Desain, implementasi, validasi dan tentukan arsitektur dasar; c) Menurunkan resiko utama dan menghasilkan estimasi jadwal dan ongkos lebih akurat. Selama elaborasi, kita mengatasi resiko utama; d) Memperhalus pengembangan dan menentukan lingkungan pengembangan.

Artifak Lifecycle Objectives yang terutama terkait dengan tujuan fase elaboration ini dirangkum dalam dokumen SRS dan dokumen SAD. Pendekatan yang bersifat agile unfied process, menampilkan model perangkat lunak dalam functional view (dengan menggunakan UML Use Case Diagram, lihat Gambar 7), logical view (dinyatakan dengan UML Class Diagram, lihat Gambar 8), process view (dinyatakan dengan UML Sequence Diagram, lihat Gambar ) dan implementation view (yang dinyatakan dengan UML Navigation Diagram). Untuk rancangan antar-muka aplikasi, digunakan Storyboard (lihat Gambar . Untuk kepentingan penulisan paper ini, maka gambar diagram yang ditampilkan dibatasi pada UML Use Case Diagram (lihat Gambar 7), UML Class Diagram (lihat Gambar 8) dan Storyboard (lihat Gambar 9)

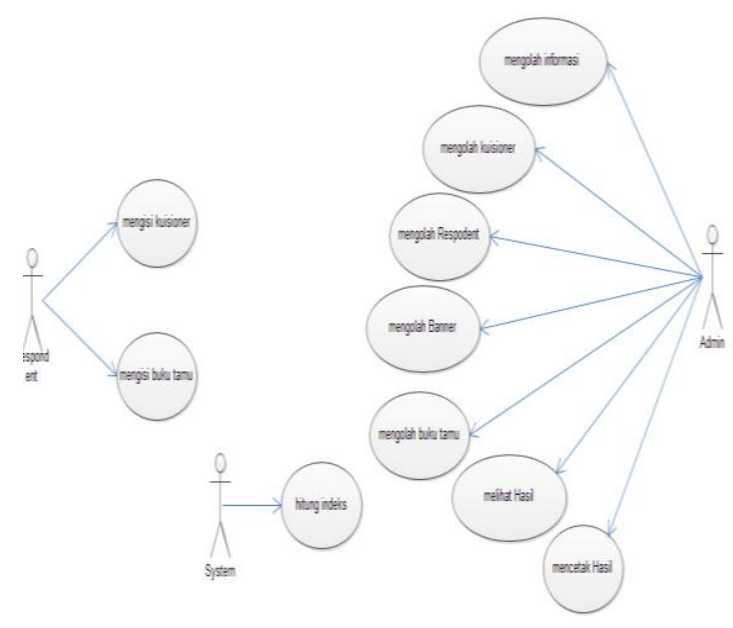

Gambar 7. UML Use Case Diagram Aplikasi 


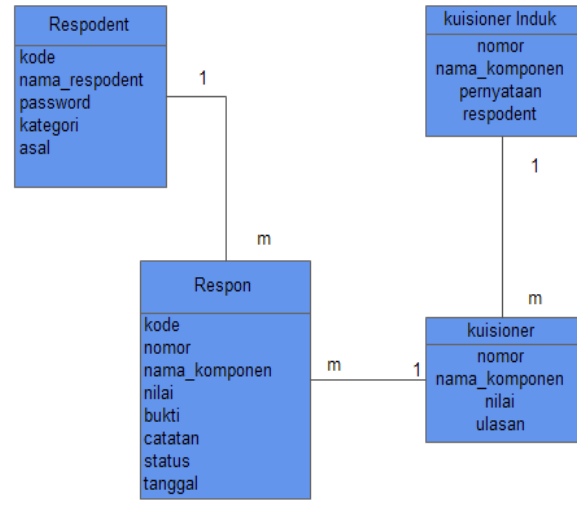

Gambar 8. UML Class Diagram Aplikasi

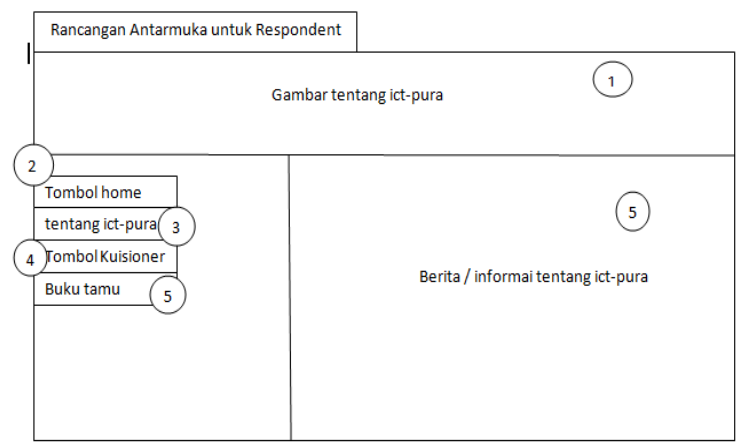

Gambar 9. Storyboard Aplikasi

\subsection{Tahap Construction}

Target utama fase construction adalah pengembangan yang efisien dan murah menuju produk akhir yaitu versi operasional sistem yang dapat dideploy ke komunitas end-user. Fase ini memiliki tujuan sbb: a) Meminimalisir ongkos pengembangan dan mencapai derajat paralelisme dalam pekerjaan yang dilakukan secara tim.; b) Mengembangkan produk lengkap secara iteratif yang akhirnya siap dipindahkan ke end-use community. Artifak dokumen yang dihasilkan pada fase ini diantaranya adalah Coding Program, Skenario Testing, Dokumentasi Hasil Pengujian. Untuk penulisan paper ini, penulis hanya menampilkan snapshot coding dan halaman tampilan dari coding tersebut (lihat Gambar 10).

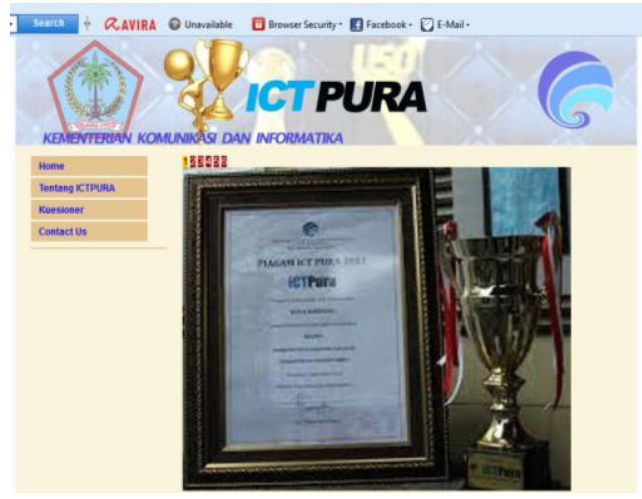

Gambar 10. Tampilan Antarmuka Home

$<$ head $>$

$<$ title>ICT Pura<?php include "Admin/koneksi.php" ?></title> $<$ meta http-equiv="Content-Type" content="text/html; charset=utf$8 " />$

$<$ meta name="author" content $=$ "Ayu" $>$

$<$ meta name="description" content="ICT">

$<$ meta name="keywords" content="ICT">

$<$ link href="ictStyle.css" rel="stylesheet" type="text/css" / >

<script language="javascript" src="js/jquery-1.4.js" $\rangle\langle/$ script $\rangle$

$<$ script type="text/javascript" src="js/tinydropdown.js" $\rangle\langle/$ script $\rangle$

$\langle$ script language $="$ javascript" $\mathrm{src}=" \mathrm{js} /$ headline.js" $\rangle\langle/$ script $\rangle$

$<$ script type="text/javascript" >

$\$$ (document).ready(function()

bukaContent(\$('\#slideAwal'),'div1');

\}$)$

$</$ script $>$

<script src="js/newsticker.js" type="text/javascript" $\rangle\langle/$ script $\rangle$

$</$ head $>$

$<$ body $>$

$<$ div id="wrapper" $>$

$<$ div id="header" $></$ div $>$

$\langle$ div id="leftcontent" $>$

$<\mathrm{p}>$

$<$ ?php include "ictKiri.php"; ?>

$</ \mathrm{p}>$

$</ \operatorname{div}>$

$<$ div id="middlecontent" >

$<\mathrm{p}>$

$<$ ?php include "ictMiddle.php"; ?>

$</ \mathrm{p}>$

$</$ div $>$

$\langle$ div id="clearer" $>\langle/$ div $>$

$<$ div id="footer" $>$

Copyright \&copy; 2013 by Wahjoe Dyah Ayuningtyas -

UNSRAT Manado

$</$ div $>$

$</$ div $>$

$<$ script type="text/javascript" $>$

var dropdown=new TINY.dropdown.init("dropdown", \{id:'menu',

active:'menuhover'\});

$</$ script $>$

$</$ body $>$

$</$ html $>$ 


\section{SIMPULAN DAN SARAN}

Beberapa kesimpulan yang di dapat oleh peneliti adalah sebagai berikut :

1. Perancangan Aplikasi Perhitungan Indeks ICTPURA ini dapat meningkatkan dan menentukan tingkat kesiapan suatu kota dalam menghadapi era digital di Sulawesi Utara

2. Metodologi DAD (disciplined agile delivery ) berpedoman pada pendekatan agile, dengan panduan Pusilkom Agile Unified Process (PAUS) menjamin pengembangan aplikasi yang architecure-centric, model-based, objectoriented dalam waktu relatif singkat. Metodologi DAD memberikan kecepatan dan kelengkapan dokumentasi dalam pengembangan sistem informasi.

3. Aplikasi ini dibuat untuk dijadikan tools dalam program apresiasi ICT-PURA dalam keikutsertaan provinsi Sulawesi Utara.

\section{DAFTAR RUJUKAN}

[1] KEMENKOMIFO,2011, Profil dan Panduan Pelaksanaan Program ICT-pura, Jakarta.

[2] Andri Kristanto, 2010, Kupas Tuntas PHP dan MySQL, penerbit cable book, Klaten.

[3] Roger S.Pressman,Ph.D, 2012, Rekayasa Perangkat Lunak , penerbit ANDI ,Yogjakarta.

[4] A.M. Hirin dan Virgi, 2011, Cepat Mahir Pemrograman Web dengan Menggunakan PHP dan MySQL, Prestasi Pustaka Publisher, Jakarta.

[5] Karouw, Stanley. 2012. Analisa dan Perancangan Portal Web Amazing North Sulawesi dengan menggunakan Metode Agile Unified Process (AUP). Manado.

[6] Erick Kurniawan, Antonius Rachmat, 2010, Teknologi Informasi dan Komunikasi, Penerbit Pusat Perbukuan, Jakarta 